\title{
Induction of heme oxygenase-1 attenuates lipopolysaccharide-induced cyclooxygenase-2 expression in mouse brain endothelial cells
}

\author{
Ruey-Horng Shih, Chuen-Mao Yang ${ }^{*}$
}

\begin{abstract}
Background: Prostaglandin $E_{2}\left(P_{G} E_{2}\right)$, an arachidonic acid metabolite converted by cyclooxygenase-2 (COX-2), plays important roles in the regulation of endothelial functions in response to bacterial infection. The enzymatic activity of COX-2 can be down-regulated by heme oxygenase-1 (HO-1) induction. However, the mechanisms underlying HO-1 modulating COX-2 protein expression are not known.

Objective: The aim of the present study was to investigate whether the up-regulation of HO-1 regulates COX-2 expression induced by lipopolysaccharide (LPS), an endotoxin produced by Gram negative bacteria, in mouse brain endothelial cells (bEnd.3)

Methods: Cultured bEnd.3 cells were used to investigate LPS-induced COX-2 expression and $\mathrm{PGE}_{2}$ production. Cobalt protoporphyrin IX (COPP, an HO-1 inducer), infection with a recombinant adenovirus carried with HO-1 gene (Adv-HO-1), or zinc protoporphyrin (ZnPP, an HO-1 inhibitor) was used to stimulate HO-1 induction or inhibit HO-1 activity. The expressions of COX-2 and $\mathrm{HO}-1$ were evaluated by western blotting. $\mathrm{PGE}_{2}$ levels were detected by an enzyme-linked immunoassay. Hemoglobin (a chelator of carbon monoxide, $\mathrm{CO}$, one of metabolites of HO-1) and CO-RM2 (a CO releasing molecule) were used to investigate the mechanisms of HO-1 regulating COX-2 expression.
\end{abstract}

Results: We found that LPS-induced COX-2 expression and PGE 2 production were mediated through NF- $\kappa \mathrm{B}$ (p65) via activation of Toll-like receptor 4 (TLR4). LPS-induced COX-2 expression was inhibited by HO-1 induction by pretreatment with CoPP or infection with Adv-HO-1. This inhibitory effect of HO-1 was reversed by pretreatment with either ZnPP or hemoglobin. Pretreatment with CO-RM2 also inhibited TLR4/MyD88 complex formation, NF- $\kappa \mathrm{B}$ (p65) activation, COX-2 expression, and $\mathrm{PGE}_{2}$ production induced by LPS.

Conclusions: We show here a novel inhibition of HO-1 on LPS-induced COX-2/PGE 2 production in bEnd.3. Our results reinforce the emerging role of cerebral endothelium-derived $\mathrm{HO}-1$ as a protector against cerebral vascular inflammation triggered by bacterial infection.

\section{Background}

Sepsis is a life-threatening clinical syndrome which is correlated with a mortality of 30\% [1]. During Gram negative sepsis, lipopolysaccharide (LPS), an endotoxin produced by Gram negative bacteria, stimulates various pro-inflammatory cytokines and mediators releasing [2]. For example, prostaglandin $\mathrm{E}_{2}\left(\mathrm{PGE}_{2}\right)$, an arachidonic acid metabolite synthesized by cyclooxygenase-2

\footnotetext{
* Correspondence: chuenmao@mail.cgu.edu.tw

Department of Physiology and Pharmacology, Chang Gung University, Kwei-San, Tao-Yuan, Taiwan
}

(COX-2) which is a key enzyme involved in the LPS-induced inflammatory process [3], is a potent proinflammatory mediator and plays important physiologi$\mathrm{cal} /$ pathological roles in the regulation of vascular endothelial function $[4,5]$.

LPS may reach the brain tissue via blood stream and induce neuronal injury during bacterial infection [6]. LPS-induced brain inflammation was closely associated with increased oxidative stress $[7,8]$. Therefore, LPS has been extensively used to study the possible linkage between inflammation and brain injury [9]. In the brain, 
cerebrovascular endothelial damage induced by oxidative stress have been reported to be diminished by heme oxygenase-1 (HO-1) [10-12], an inducible form of $\mathrm{HO}$ which is an enzyme catalyzing the degradation of heme into carbon monoxide (CO), biliverdin, and free iron. HO-1 is one of the major acute-phase proteins upregulated upon exposure to oxidative stresses [13-15]. Moreover, increasing evidence indicates that $\mathrm{CO}$, a byproduct of HO-1, may protect against LPS-induced endothelial injury, suggesting that the production of $\mathrm{CO}$ by $\mathrm{HO}-1$ exerts protective effects against LPS-induced endothelial injury [16].

COX-2 is an enzymatic heme protein [17]. HO-1 controls the availability of heme for synthesis of enzymatic heme proteins (e.g. $\mathrm{COX}-2$ ), and generates $\mathrm{CO}$, which binds the heme moiety of heme protein thus affecting their enzymatic activity [18]. In consequence, the effect of $\mathrm{HO}-1$ on COX-2 protein in vascular endothelial cells is one of significant physiological/pathological modulation. However, there are few studies investigating whether the up-regulation of COX-2 protein can be modulated by HO-1. The effect of HO-1 on LPSinduced COX-2 expression in cerebral endothelial cells has not yet been elucidated.

Thus, experiments were performed using a mouse brain endothelial cell line (bEnd.3) to investigate whether HO-1 regulates LPS-induced COX-2 expression in these cells. Our results demonstrate that LPS-induced COX-2 expression and $\mathrm{PGE}_{2}$ production is inhibited by induction of $\mathrm{HO}-1$. This inhibitory effect of $\mathrm{HO}-1$ is mediated through an $\mathrm{HO}-1$ byproduct, $\mathrm{CO}$, which attenuates TLR4/MyD88 complex formation and NF- $\kappa \mathrm{B}$ activation induced by LPS. These results suggest that cerebrovascular endothelium-derived HO-1 may prevent vascular inflammation which is triggered by bacterial infection in the brain.

\section{Methods}

\section{Materials}

Dulbecco's modified Eagle's medium (DMEM) and fetal bovine serum (FBS) were purchased from Invitrogen (Carlsbad, CA, USA). Polyclonal antibodies HO-1, TLR4, and MyD88 were purchased from Santa Cruz (Santa Cruz, CA, USA). Anti-COX-2 antibody was purchased from BD Transduction Laboratories (San Diego, CA, USA). Anti-GAPDH antibody was purchased from Biogenesis (Boumemouth, UK). Anti-phospho-NF- $\kappa$ B p65 antibody was purchased from Cell Signaling (Danver, MA, USA). Bay117082 was purchased from Biomol (Plymouth Meeting, PA, USA). Bicinchoninic acid (BCA) protein assay reagent was purchased from Pierce (Rockford, IL, USA). Hemoglobin, biliverdin reductase, enzymes, and other chemicals were purchased from Sigma (St. Louis, MO, USA).

\section{Cell cultures}

Mouse brain endothelial cells (bEnd.3, ATCC CRL2299) were grown in DMEM/F-12 containing $10 \%$ FBS and antibiotics $(100 \mathrm{U} / \mathrm{ml}$ penicillin G, $100 \mu \mathrm{g} / \mathrm{ml}$ streptomycin, and $250 \mathrm{ng} / \mathrm{ml}$ fungizone) at $37^{\circ} \mathrm{C}$ in a humidified $5 \% \mathrm{CO}_{2}$ atmosphere. When the cultures grew to confluence (about 4 days), cells were detached with $0.05 \%(\mathrm{w} / \mathrm{v})$ trypsin $/ 0.53 \mathrm{mM}$ EDTA for $5 \mathrm{~min}$ at $37^{\circ} \mathrm{C}$. The cell suspension was diluted with DMEM/F-12 containing $10 \%$ FBS to a concentration of $2 \times 10^{5}$ cells $/ \mathrm{ml}$. The cell suspension was plated onto 12 -well culture plates $(1 \mathrm{ml} /$ well $)$ for the measurement of protein expression and enzymatic assays. Culture medium was changed after $24 \mathrm{~h}$ and every 3 days. Experiments were performed with cells from passages 5 to 13 .

\section{Preparation of recombinant adenovirus infection}

A recombinant adenovirus containing HO-1 (Adv-HO-1) was kindly provided by Dr. L.Y. Chau (Institute of Biomedical Sciences, Academia Sinica, Taipei, Taiwan). Recombinant adenovirus was generated by homologous recombination and amplified in 293 cells. Large scales of viral vectors were purified by $\mathrm{CsCl}$ ultracentrifugation and stored in $10 \mathrm{mM}$ Tris- $\mathrm{HCl}(\mathrm{pH} 7.4), 1 \mathrm{mM} \mathrm{MgCl}_{2}$, and $10 \%(\mathrm{v} / \mathrm{v})$ glycerol at $-80^{\circ} \mathrm{C}$ until used for experiments. Virus titers were determined by a plaque assay on a 293 cell monolayer. The recombinant adenovirus was diluted with DMEM/F12 medium and added directly to the cells $(\mathrm{MOI}=10)$. After $24 \mathrm{~h}$ of infection, the cells were incubated with LPS for another $24 \mathrm{~h}$. Cell lysates were analyzed by western blotting.

\section{II extract preparation and western blot}

Western blot analysis was performed as previously described [19]. bEnd.3 cells were lysed with a sample buffer (125 mM Tris-BASE, 5\% Glycerol, 3\% $\beta$-mercaptoethanol, $1.25 \%$ SDS and $0.0005 \%$ Bromophenol blue). Cell lysates were denatured, subjected to SDSPAGE using a $12 \%$ running gel and transferred onto a nitrocellulose membrane. Membranes were incubated with a mouse anti-COX-2 antibody (1:1000 dilution) or a goat anti-HO-1 antibody (1:1000 dilution) at $4{ }^{\circ} \mathrm{C}$ for $24 \mathrm{~h}$, and then incubated with an anti-mouse or anti-goat horseradish peroxidase antibody (1:2000 dilution, at room temperature for $1 \mathrm{~h}$ ), respectively. The gel bands were detected by ECL reagents and were quantified by a densitometry.

\section{Immunoprecipitation assay}

The bEnd. 3 cells were grown to confluence and starved for $24 \mathrm{~h}$ in serum-free DMEM/F-12 medium. Cells were pretreated with CO-RM2 (CO releasing molecule, 50 $\mu \mathrm{M})$ for $2 \mathrm{~h}$ prior to the application of LPS. The cells were washed, scraped, and centrifuged to prepare 
membrane, cytosolic, and nuclear fractions, as previously described [20]. Membrane fractions containing $1 \mathrm{mg}$ of protein were incubated with $2 \mu \mathrm{g}$ of anti-TLR4 antibody at $4^{\circ} \mathrm{C}$ for $24 \mathrm{~h}$, and then $10 \mu \mathrm{l}$ of $50 \%$ protein A-agarose beads was added and mixed at $4{ }^{\circ} \mathrm{C}$ for another $24 \mathrm{~h}$. The immunoprecipitates were collected and subjected to electrophoresis on $12 \%$ SDS-PAGE, transferred to nitrocellulose membrane, and then blotted using an antiMyD88 or anti-TLR4 antibody. The gel bands were detected by ECL reagents and were quantified by a densitometry.

\section{Enzymatic assay for HO-1 activity}

$\mathrm{HO}$ activity was measured as the level of bilirubin formation using the microsomal fraction of cells [21]. Briefly, bEnd. 3 cells were washed twice with PBS, gently scraped off the dish, and centrifuged $(1000 \times \mathrm{g}, 10 \mathrm{~min}$, $\left.4^{\circ} \mathrm{C}\right)$. The cell pellet was suspended in $\mathrm{MgCl}_{2}(2 \mathrm{mM})$ and phosphate $(100 \mathrm{mM})$ buffer $(\mathrm{pH} 7.4)$, frozen at $-70^{\circ} \mathrm{C}$, thawed thrice, and finally sonicated on ice before centrifugation at $18,000 \times \mathrm{g}$ for $10 \mathrm{~min}$ at $4^{\circ} \mathrm{C}$. The supernatant $(400 \mu \mathrm{l})$ was added to a reaction mixture $(200 \mu \mathrm{l}$ final volume, $\mathrm{pH}$ 7.4) containing NADPH $(0.8 \mathrm{mM})$, glucose- 6 -phosphate $(2 \mathrm{mM})$, glucose- 6 phosphate-1-dehydrogenase $(0.2 \mathrm{U})$, and $2 \mathrm{mg}$ of rat liver cytosol as a source of biliverdin reductase, PBS $(100 \mathrm{mM})$, and the substrate hemin $(10 \mu \mathrm{M})$. The reaction was conducted for $1 \mathrm{~h}$ at $37^{\circ} \mathrm{C}$ in the dark and terminated by addition of $1 \mathrm{ml}$ chloroform. The reaction without the NADH served as a control. The extracted bilirubin was measured by the difference in absorption between 464 and $530 \mathrm{~nm}$ (extinction coefficient $=40$ $\mathrm{mM}^{-1} \cdot \mathrm{cm}^{-1}$ ) with a spectrophotometer. $\mathrm{HO}$ activity was expressed as picomoles of bilirubin per milligram of protein per hour.

\section{Measurement of $\mathrm{PGE}_{2}$ generation}

bEnd.3 cells were cultured in 12-well culture plates. After reaching confluence, cells were pretreated with $\mathrm{CoPP}, \mathrm{ZnPP}$, or CO-RM2 for the indicated time intervals, and then incubated with LPS $(100 \mu \mathrm{g} / \mathrm{ml})$ at $37^{\circ} \mathrm{C}$ for $24 \mathrm{~h}$. The levels of $\mathrm{PGE}_{2}$ released into the culture medium were collected and stored at $-80^{\circ} \mathrm{C}$ until being assayed by using a commercially available $\mathrm{PGE}_{2}$ enzyme immunoassay kit (Cayman Chemicals, Ann Arbor, MI). Both the samples and standards were assayed in parallel.

\section{Statistical analysis of data}

Data were analyzed using a GraphPad Prism Program (GraphPad, San Diego, CA, USA). Quantitative data were analyzed using one-way analysis of variance (ANOVA) followed by Tukey's honestly significant difference tests between individual groups. Data were expressed as mean \pm SEM. A value of $P<0.05$ was considered significant.

\section{Results \\ LPS induces COX-2 expression and $\mathrm{PGE}_{2}$ synthesis in bEnd. 3 cells}

To determine the effect of LPS on COX-2 expression, bEnd. 3 cells were incubated with various concentrations of LPS for the indicated time intervals. As shown in Figure $1 \mathrm{~A}$ and $1 \mathrm{~B}$, LPS induced COX-2 expression in a time- and concentration-dependent manner. LPS (100 $\mu \mathrm{g} / \mathrm{ml}$ )-induced COX-2 protein expression was significantly increased within $6 \mathrm{~h}$ and sustained over $24 \mathrm{~h}$. To further determine if LPS-induced COX-2 expression required ongoing transcription or translation, cells were pretreated with either a transcriptional level inhibitor [actinomycin D (Act.D)] or a translational level inhibitor [cycloheximide (CHI)] for $1 \mathrm{~h}$ and then incubated with LPS $(100 \mu \mathrm{g} / \mathrm{ml})$ for $24 \mathrm{~h}$. As shown in Figure $1 \mathrm{C}$ and $1 \mathrm{D}$, LPS-mediated induction of COX-2 expression was abolished by pretreatment with either Act.D or CHI in a concentration-dependent manner. Pretreatment with these two inhibitors alone had no effect on COX-2 expression. In addition, we found that LPS $(100 \mu \mathrm{g} / \mathrm{ml})$ markedly increased COX-2 enzyme activity, revealed as $\mathrm{PGE}_{2}$ production (Figure $1 \mathrm{E}$ ). Taken together, these findings demonstrated that the induction of COX-2 by LPS depends on de novo protein synthesis.

\section{LPS-induced COX-2 expression is mediated through NF- $\kappa \mathrm{B}$ activation}

To investigate the role of $\mathrm{NF}-\kappa \mathrm{B}$ in LPS-mediated COX-2 expression, cells were pretreated with an inhibitor of NF- $\kappa \mathrm{B}$, Bay117082 for $1 \mathrm{~h}$, and then incubated with LPS for $24 \mathrm{~h}$. As shown in Figure 2A, Bay117082 markedly inhibited LPS-induced COX-2 expression, suggesting that NF- $\kappa \mathrm{B}$ may play an important role in LPSinduced COX-2 expression. Next, we investigated whether the involvement of NF- $\kappa \mathrm{B}$ in LPS-mediated responses was mediated through activation of NF- $\kappa \mathrm{B}$ (p65). As shown in Figure 2B, LPS stimulated phosphorylation of NF- $\kappa \mathrm{B}$ (p65) in a time-dependent manner, which was inhibited by pretreatment with Bay117082. To further investigate whether activation of NF $-\kappa \mathrm{B}$ was mediated through TLR4 receptors, cells were pretreated with a TLR4 antibody $(5 \mathrm{mg} / \mathrm{ml})$ for 1 $h$, and then incubated with LPS for the indicated time intervals. As shown in Figure 2C, pretreatment with TLR4 antibody also inhibited LPS-stimulated phosphorylation of NF- $\kappa \mathrm{B}$ (p65). These data indicated that LPSinduced COX-2 expression was mediated through a TLR4/NF- $\kappa$ B cascade in bEnd.3 cells. 


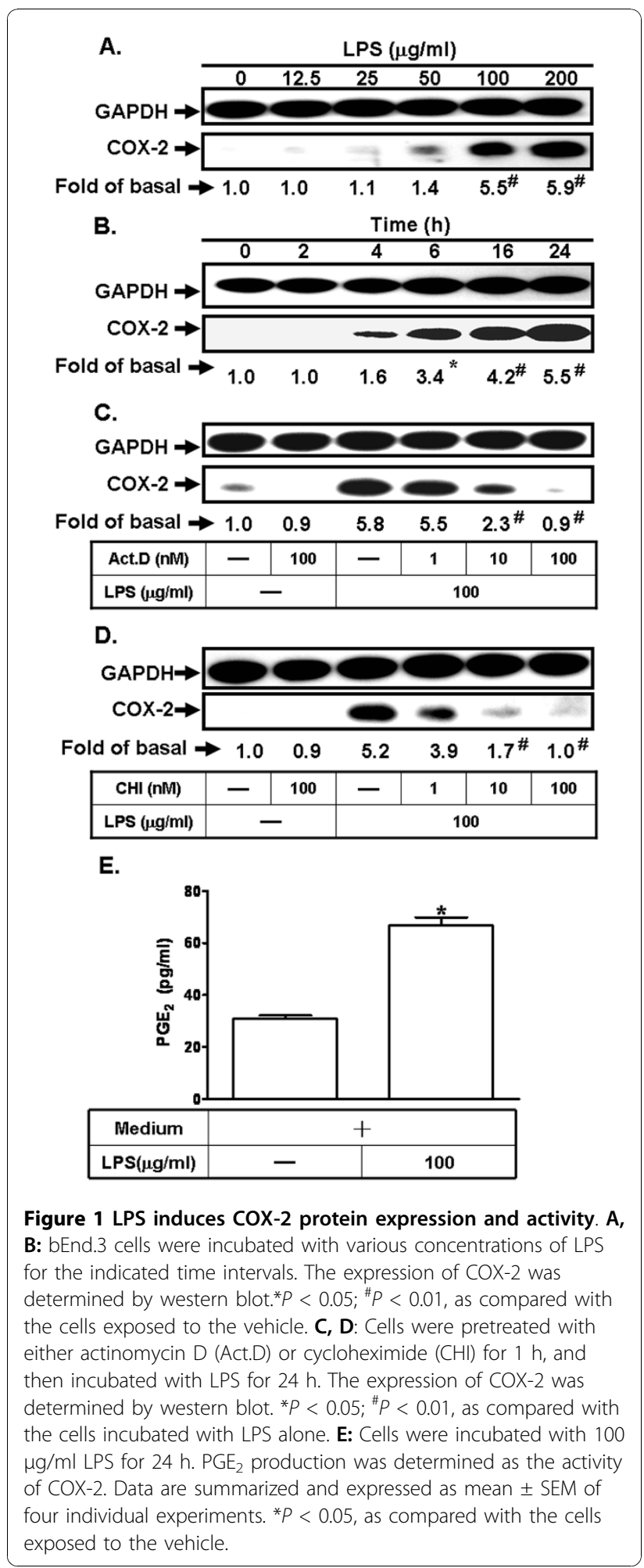

Pretreatment with CoPP attenuates LPS-induced COX-2 expression and NF- $\kappa$ B (p65) phosphorylation

HO-1 has been shown to exert cytoprotective and antiinflammatory effects in stress conditions. Therefore, we

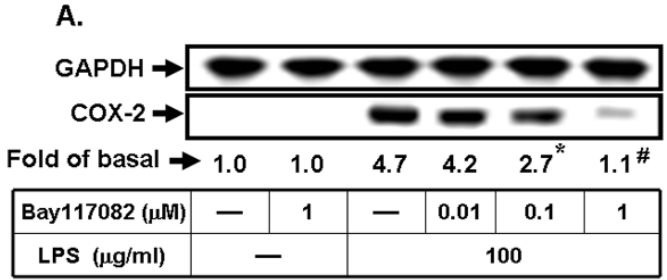

B.
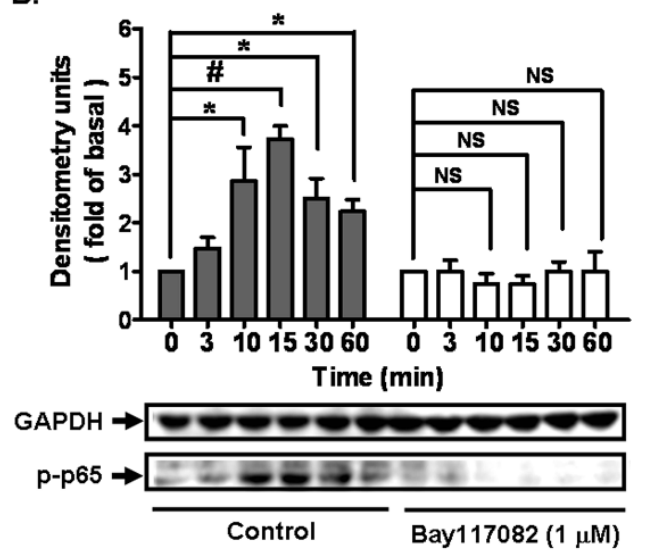

c.

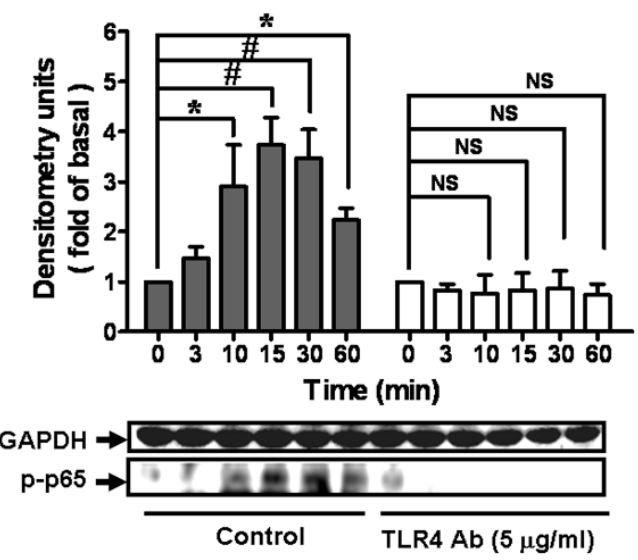

Figure 2 LPS-induced COX-2 expression via NF- $\kappa$ B activation. A: Cells were pretreated with an inhibitor of NF- $\kappa$ B, Bay 117082 , for $1 \mathrm{~h}$ and then incubated with LPS $(100 \mathrm{mg} / \mathrm{ml})$ for $24 \mathrm{~h}$. The expression of COX-2 was determined by western blot. ${ }^{*} P<0.05$; ${ }^{\# P}<0.01$, as compared with the cells incubated with LPS alone. B, C: Cells were pretreated with either Bay117082 or TLR 4 antibody for $1 \mathrm{~h}$ and then stimulated with LPS $(100 \mathrm{mg} / \mathrm{ml})$ for the indicated time intervals. Phosphorylation of NF- $\kappa \mathrm{B}$ p 65 was determined by western blot. Data are summarized and expressed as mean \pm SEM of four individual experiments. ${ }^{*} P<0.05 ;{ }^{\#} P<0.01$ as compared within groups. NS: not significant.

investigated whether induction of HO-1 attenuated LPS-mediated responses in bEnd. 3 cells. As shown in Figure $3 \mathrm{~A}$, pretreatment with CoPP (an $\mathrm{HO}-1$ inducer) induced $\mathrm{HO}-1$ protein expression in a concentrationdependent manner in bEnd.3 cells. Pretreatment with CoPP $(0.3 \mu \mathrm{M})$ for $24 \mathrm{~h}$ markedly increased HO-1 
enzyme activity which was attenuated by $\mathrm{ZnPP}$ (an HO-1 activity inhibitor) (Figure 3B). Interestingly, pretreatment with CoPP resulted in a significant attenuation of LPSinduced COX-2 protein expression (Figure $3 \mathrm{C}$ ). NF- $\kappa \mathrm{B}$ is a crucial transcription factor for $\mathrm{COX}-2$ expression, we determined the effect of HO-1 on LPS-stimulated NF- $\kappa$ B activation by measuring NF- $\kappa \mathrm{B}(\mathrm{p} 65)$ phopshorylation. As shown in Figure 3D, LPS-stimulated NF- $\kappa$ B (p65) phosphorylation was also inhibited by pretreatment with CoPP $(0.3 \mu \mathrm{M}, 24 \mathrm{~h})$, during the period of observation. These data indicated that LPS-induced COX-2 expression and NF- $\kappa \mathrm{B}$ (p65) phosphorylation was attenuated by up-regulation of HO-1 in bEnd. 3 cells.

\section{HO-1 over-expression attenuates LPS-induced COX-2 expression and $\mathrm{PGE}_{2}$ synthesis}

To ensure that HO-1 induction decreased LPS-induced COX-2 expression, bEnd. 3 cells were pretreated with an $\mathrm{HO}-1$ inducer (CoPP) or an $\mathrm{HO}-1$ functional inhibitor (ZnPP). As shown in Figure 4A, pretreatment with CoPP attenuated LPS-induced COX-2 protein expression and $\mathrm{PGE}_{2}$ synthesis. These inhibitory effects of $\mathrm{CoPP}$ were reversed by ZnPP. To further confirm the effect of HO-1 overexpression induced by CoPP on LPS-mediated responses, bEnd. 3 cells were transfected with either adenovirus or recombinant adenovirus carrying the human HO-1 (Adv-HO-1). As shown in Figure $4 \mathrm{~B}$, transfection with adv-HO-1 ( $\mathrm{Adv}, \mathrm{MOI}=10,48 \mathrm{~h}$ ) enhanced HO-1 expression and attenuated LPS-induced COX-2 expression. In contrast, transfection with adenovirus alone had no effect on HO-1 and COX-2 experssion. This inhibitory effect was reversed by a chelator of carbon monoxide, hemoglobin $(\mathrm{Hb}, 200 \mathrm{mg} / \mathrm{ml})$. These results suggested that overexpression of $\mathrm{HO}-1$ by pretreatment with CoPP or transfection with adv-HO-1 attenuated LPS-induced COX-2 expression, at least in part, mediated through an $\mathrm{HO}-1$ byproduct, $\mathrm{CO}$.

\section{CO inhibits LPS-induced COX-2 expression and $\mathrm{PGE}_{2}$ synthesis in bEnd. 3 cells}

To further determine whether CO attenuated LPSinduced COX-2 expression, bEnd.3 cells were pretreated with a $\mathrm{CO}$ releasing molecule (CO-RM2). As shown in Figure 5A, LPS-induced COX-2 protein expression was inhibited by pretreatment with CO-RM2 in a concentration manner. Pretreatment with CO-RM2 also attenuated LPS-induced $\mathrm{PGE}_{2}$ synthesis (Figure $5 \mathrm{~B}$ ). We further determined whether the inhibitory effect of $\mathrm{CO}$ on LPS-induced responses was due to the attenuation of NF- $\kappa \mathrm{B}$ activation. As shown in Figure 5C, LPSstimulated NF- $\kappa \mathrm{B}$ (p65) phosphorylation was also inhibited by pretreatment with CO-RM2.

LPS has been shown to activate NF- $\kappa \mathrm{B}$ mediated through TLR4 leading to the expression of COX-2 [22].
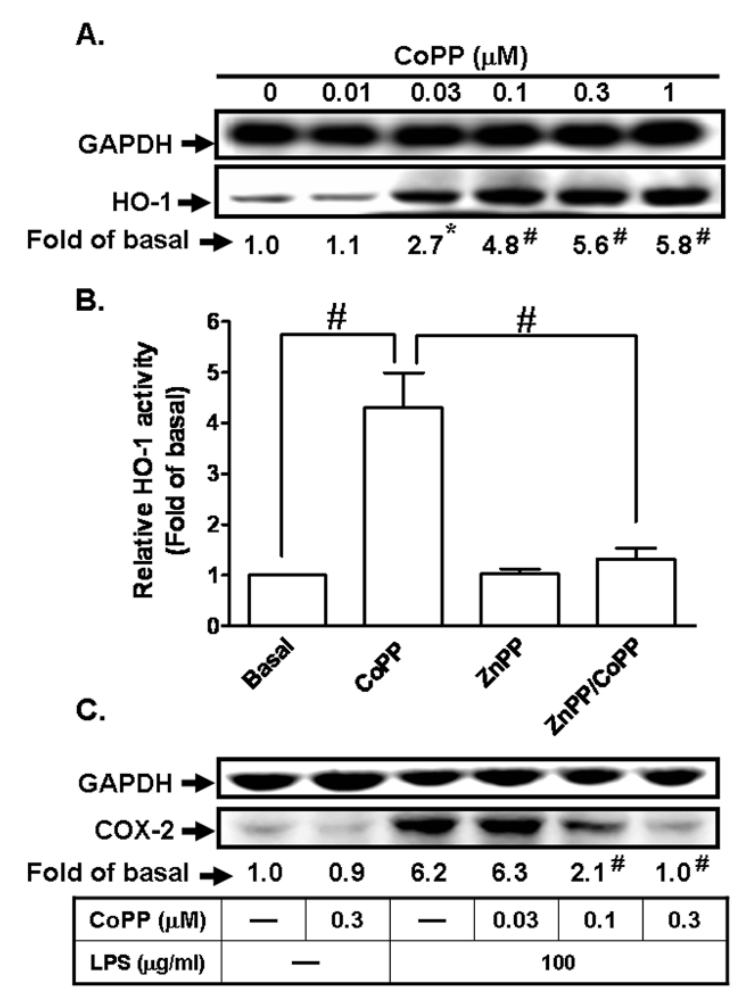

D.

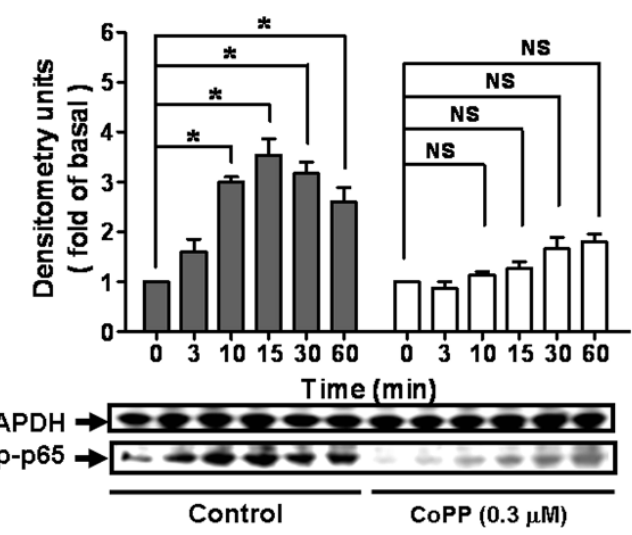

Figure 3 LPS-induced COX-2 expression is attenuated by pretreatment with CoPP in bEnd.3 cells. A: Cells were incubated with various concentrations of COPP for $24 \mathrm{~h}$. Expression of $\mathrm{HO}-1$ was determined by western blot. ${ }^{*} P<0.05 ;{ }^{*} P<0.01$ as compared the cells incubated with vehicle alone. B: Cells were pretreated with vehicle or $\mathrm{ZnPP}(0.1 \mu \mathrm{M})$ for $1 \mathrm{~h}$ and then incubated with CoPP $(0.3 \mu \mathrm{M})$ for $24 \mathrm{~h}$. HO-1 enzyme activity was determined. ${ }^{\#} P<0.01$ as compared within groups. C: Cells were pretreated with various concentrations of CoPP for $24 \mathrm{~h}$ and then incubated with LPS $(100 \mathrm{mg} / \mathrm{ml})$ for $24 \mathrm{~h}$. The expression of COX-2 was determined by western blot. ${ }^{*} P<0.05 ;{ }^{\#} P<0.01$, as compared with the cells incubated with LPS alone. D: Cells were pretreated with CoPP $(0.3 \mu \mathrm{M})$ for $24 \mathrm{~h}$ and then stimulated with LPS $(100 \mathrm{mg} / \mathrm{ml})$ for the indicated time intervals. The phosphorylation of NF- $\kappa$ B p65 was determined by western blot. Data are summarized and expressed as mean \pm SEM of four individual experiments. ${ }^{*} P<0.05$; ${ }^{\#} P<0.01$, as compared within groups. NS: not significant. 
A.
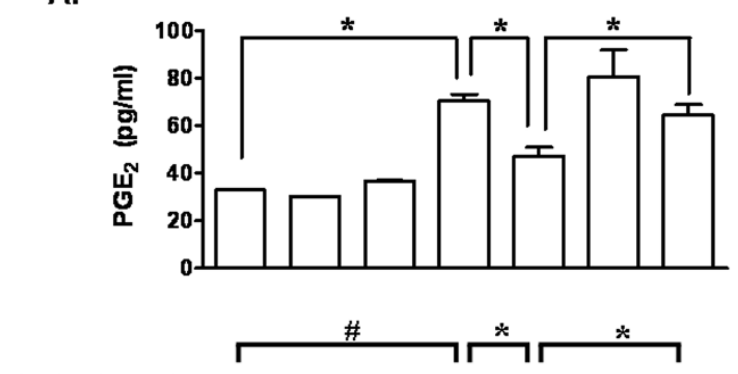

Fold of basal $\rightarrow \begin{array}{lllllll}1.0 & 1.0 & 1.3 & 4.6 & 2.1 & 5.3 & 3.8\end{array}$

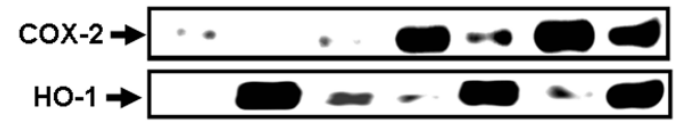

GAPDH $\rightarrow \longrightarrow \longrightarrow \longrightarrow \longrightarrow$

\begin{tabular}{|c|c|c|c|c|c|c|c|}
\hline CoPP $(\mu \mathrm{M})$ & - & 0.3 & \multicolumn{2}{|c|}{-} & 0.3 & - & 0.3 \\
\hline ZnPP $(\mu \mathrm{M})$ & - & 0.1 & - & 0.1 \\
\hline LPS $(\mu \mathrm{g} / \mathrm{ml})$ & \multicolumn{3}{|c|}{-} & \multicolumn{3}{|c|}{100} \\
\hline
\end{tabular}

B.
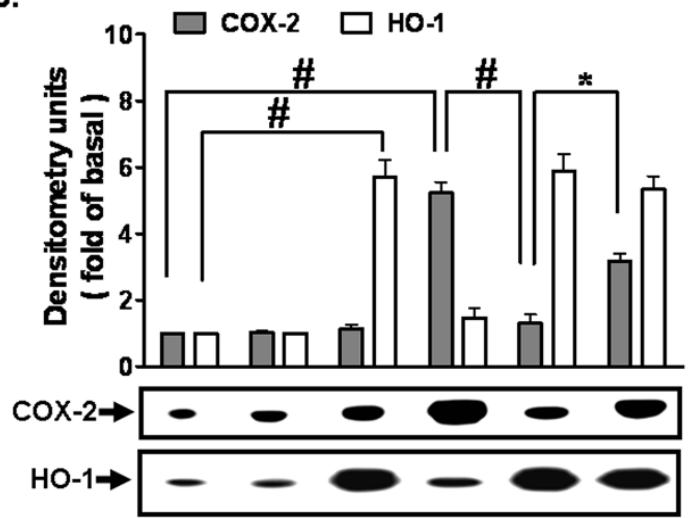

GAPDH $\rightarrow \infty \longrightarrow \bigcirc \bigcirc$

\begin{tabular}{|c|c|c|c|c|c|c|}
\hline Adv (MOl, 48h) & - & 10 & - & 10 & - & 10 \\
\hline Adv-HO-1 & \multicolumn{2}{|c|}{-} & + & - & + \\
\hline $\mathrm{Hb}(\mu \mathrm{g} / \mathrm{ml})$ & \multicolumn{3}{|c|}{-} & \multicolumn{3}{|c|}{100} \\
\hline LPS $(\mu \mathrm{g} / \mathrm{ml})$ & \multicolumn{3}{|c|}{-} & \multicolumn{3}{c|}{} \\
\hline
\end{tabular}

Figure 4 Over-expression of HO-1 attenuates LPS-induced COX-2 expression and $\mathrm{PGE}_{2}$ synthesis in bEnd.3 cells. A: Cells were pretreated with or without ZnPP for $1 \mathrm{~h}$, incubated with CoPP for $24 \mathrm{~h}$, and then incubated with LPS $(100 \mathrm{mg} / \mathrm{ml})$ for another 24 $\mathrm{h}$. The media were used to determine the levels of $\mathrm{PGE}_{2}$. The expression of COX-2 and HO-1 were determined by western blot. B: Cells were pretreated with or without hemoglobin $(\mathrm{Hb})$ for $1 \mathrm{~h}$, infected with adenovirus $(\mathrm{MOI}=10)$ or recombinant adenovirus carrying the human $\mathrm{HO}^{-1}$ gene treatment $(\mathrm{Adv}-\mathrm{HO}-1, \mathrm{MOI}=10)$ for $48 \mathrm{~h}$, and then incubated with LPS (100 mg/ml) for another $24 \mathrm{~h}$. The levels of COX-2 and HO-1 expression were determined by western blot. Data are summarized and expressed as mean \pm SEM for four individual experiments. ${ }^{*} P<0.05$; ${ }^{\#} P<0.01$ as compared within groups.

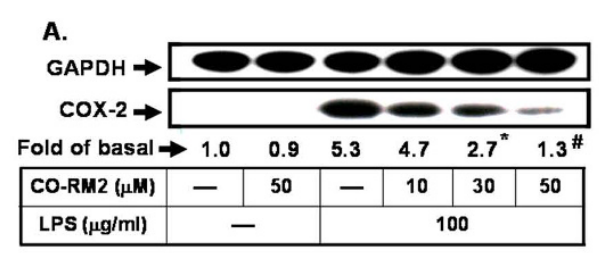

B.

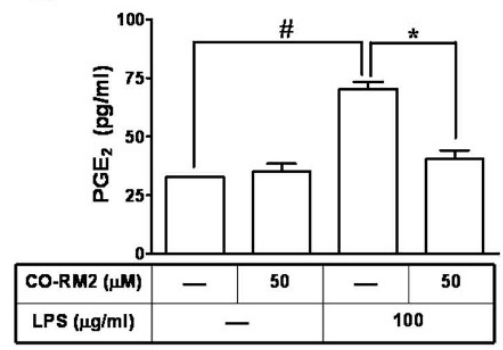

c.

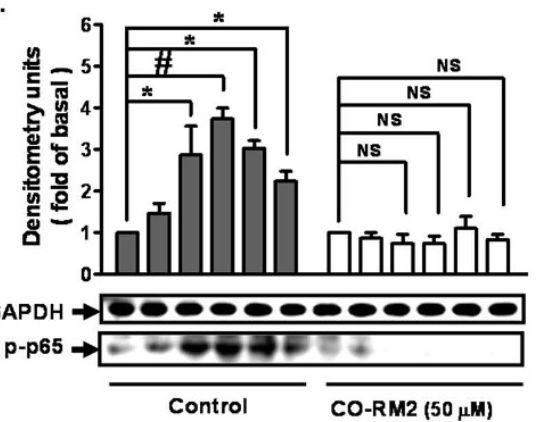

D.

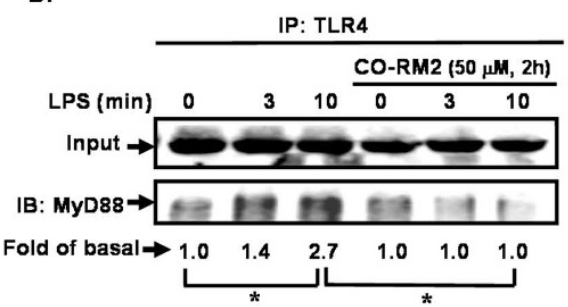

Figure 5 CO inhibits LPS-induced COX-2 protein expression and $\mathrm{PGE}_{2}$ synthesis in bEnd.3 cells. A: Cells were pretreated with CO-RM2 (CO releasing molecule) for $2 \mathrm{~h}$ and then incubated with LPS $(100 \mathrm{mg} / \mathrm{ml})$ for $24 \mathrm{~h}$. The expression of COX-2 was determined by western blot. ${ }^{*} P<0.05 ;{ }^{\#} P<0.01$, as compared with the cells incubated with LPS alone. B: Cells were pretreated with CO-RM2 (50 $\mathrm{mM}, 2 \mathrm{~h})$ and then incubated with LPS $(100 \mathrm{mg} / \mathrm{ml})$ for $24 \mathrm{~h}$. The media were used to determine the levels of $\mathrm{PGE}_{2}$. ${ }^{*} P<0.05$; ${ }^{\#} P<$ 0.01 , as compared within groups. C: Cells were pretreated with CORM2 (CO releasing molecule) for $2 \mathrm{~h}$ and then incubated with LPS $(100 \mathrm{mg} / \mathrm{ml})$ for the indicated time intervals. Phosphorylation of NF$\kappa \mathrm{B}$ p65 was determined by western blot. ${ }^{*} P<0.05 ;{ }^{\#} P<0.01$, as compared within groups. NS: not significant. D: Cells were treated with or without CO-RM2 (50 $\mu \mathrm{M}, 2 \mathrm{~h})$ followed by LPS treatment $(100 \mathrm{mg} / \mathrm{ml})$ for the indicated time intervals. Cell lysates were immunoprecipitated with an anti-TLR4 antibody. The

immunoprecipiates were analyzed by western blot using antiMyD88 or anti-TLR4 (input) antibody. Data are summarized and expressed as mean \pm SEM for four individual experiments. ${ }^{*} P<0.05$ as compared within groups. 
We therefore investigated whether $\mathrm{CO}$ regulated LPSinduced COX-2 expression through interruption of either NF- $\kappa \mathrm{B}$ or TLR4 in these cells. We tested the effect of CO-RM2 on LPS-induced protein-protein interaction between TLR4 and its adaptor protein myeloid differentiation factor (MyD88) which was shown to initiate an early activation of NF- $\kappa \mathrm{B}$ in endothelial cells [23]. As shown in Figure 5D, pretreatment with CORM2 inhibited LPS-induced TLR4/MyD88 complex formation in bEnd. 3 cells, indicating that $\mathrm{CO}$ attenuated the protein-protein interaction between TLR4 and MyD88 and thus retardation of COX-2 expression induced by LPS. These data suggested that LPS-stimulated TLR4/MyD88/NF- $\kappa \mathrm{B}$ activation and COX-2 expression was blocked by $\mathrm{CO}$ in bEnd.3 cells.

\section{Discussion}

PGs secreted by inflammatory cells are important in early initiation of inflammatory responses. $\mathrm{PGE}_{2}$ is thought to be a mediator of inflammation and pain $[4,5]$. COX-2, a key enzyme catalyzing the rate-limiting step in the inducible production of PGs, has been suggested to contribute to cellular damage. Therefore, COX-2 inhibition is suggested to be beneficial for cellular survive. In the present study, LPS-induced COX-2 expression and $\mathrm{PGE}_{2}$ synthesis was inhibited by $\mathrm{HO}-1$ induction by pretreatment with either CoPP or AdvHO-1 in murine bEnd. 3 cells. Some studies also demonstrated an inhibitory effect of HO-1 on PGs production. Up-regulation of the HO-1 gene or pretreatment with an $\mathrm{HO}-1$ inducer, $\mathrm{SnCl}_{2}$, attenuated angiotensin IIinduced COX-2 and PG synthesis in endothelial cells [24]. Pretreatment with CoPP decreased $\mathrm{PGE}_{2}$ production by inhibiting microsomal prostaglandin $\mathrm{E}$ synthase1 expression in primary cultured chondrocytes [25]. These data suggest that overexpression of HO-1 exerts an inhibitory effect on COX-2 expression and PGs production in different cell types. In contrast, an HO-1 inducer, CKD712, showed a weak inhibitory effect on COX-2 and PGE $_{2}$ induced by LPS in RAW264.7 cells [26]. Therefore, the effect of HO-1 on expression of inflammatory proteins and mediators may be controversial. In the present study, our results are the first report to show that induction of HO-1 attenuates LPS-induced COX-2 expression and $\mathrm{PGE}_{2}$ synthesis in endothelial cells. Cerebral vascular endothelium-derived HO-1 may contribute to the prevention of vascular inflammation triggered by bacterial infection in mouse brain. LPS has been shown to induce tissue injury by damaging the nutritive microcirculation and by stimulating the release of cytokines [27]. HO-1 may protect against LPS-mediated injury by attenuating the expression of inflammatory mediators and improving microvascular perfusion. In the present study, we found that pre-induction of HO-1 attenuate LPS-induced expression of COX-2 protein and therefore decreased $\mathrm{PGE}_{2}$ accumulation. The role of $\mathrm{HO}-1$ over-expression in COX-2 induction as well as $\mathrm{PGE}_{2}$ synthesis induced by various stimuli remains to be investigated.

Bernardini et al. [16] have shown that levels of HO-1, Hsp70, and Egr-1 proteins are increased within 4-15 h after LPS $(10 \mu \mathrm{g} / \mathrm{ml})$ administration in porcine aortic endothelial cells (pAEC). LPS $(10 \mu \mathrm{g} / \mathrm{ml}, 15 \mathrm{~h})$ also increases apoptosis rates about 4-7 folds in pAEC. Because $\mathrm{HO}-1$ plays a protecting role in stress conditions, it is reasonable that $10 \mu \mathrm{g} / \mathrm{ml}$ of LPS damaged the pAEC and also induced HO-1 protein expression to defend against the injury insults. In our study, there was no COX-2 protein expression induced by LPS at $25 \mu \mathrm{g} / \mathrm{ml}$ for $24 \mathrm{~h}$. The required concentration of LPS to induce significant COX-2 protein expression in bEnd. 3 cells was a concentration of $100 \mu \mathrm{g} / \mathrm{ml}$ for $24 \mathrm{~h}$. At this concentration, neither was cell damage observed nor HO-1 expression increased in bEnd. 3 cells. This discrepancy may be due to different experimental conditions or to cell specificity.

Carbon monoxide $(\mathrm{CO})$ is one of the main metabolites of heme degradation by HO-1 $[28,29]$. Its antiinflammatory, anti-apoptotic and cytoprotective properties are well documented in different experimental models [15]. There is growing evidence to demonstrate the role of $\mathrm{CO}$ as anti-inflammatory and cytoprotective functions of $\mathrm{HO}-1$ in various cell types [30-32]. The $\mathrm{HO} / \mathrm{CO}$ signaling pathway plays an important role in host defense mechanisms, including inhibition of TLR4 signaling stimulated by LPS [33-35]. In the present study, LPS-induced COX-2 expression and $\mathrm{PGE}_{2}$ production was inhibited by pretreatment with either CoPP or CO-RM2. This inhibitory effect was reversed by pretreatment with $\mathrm{ZnPP}$, an HO-1 activity inhibitor, and hemoglobin, a chelator of $\mathrm{CO}$, suggesting that the inhibitory effect of HO-1 on COX-2 expression was partially mediated through CO. Consistent with our report, $\mathrm{CO}$ has been shown to down-regulate LPS-induced COX-2 expression and $\mathrm{PGE}_{2}$ secretion by inhibiting CCAAT/enhancer-binding protein (C/EBP) in LPS-treated RAW 264.7 cells [36]. In addition to $\mathrm{CO}$, biliverdin and bilirubin have been reported to protect cells from the insult of oxidative stress in HO-1 siRNA-transfected HT22 cells [37]. The roles of biliverdin and bilirubin on LPS-induced COX2 expression needs further investigating.

The transcription factor NF- $\kappa \mathrm{B}$ is a major mediator of LPS signaling [38]. LPS-activated NF- $\kappa \mathrm{B}$ is an important transcription factor for expression of inflammatory proteins. NF- $\kappa \mathrm{B}$ is a downstream component of tyrosine phosphorylation. LPS has been shown to activate NF- $\kappa \mathrm{B}$ through TLR4 leading to the expression of COX-2 [22]. It has also been reported that the attenuation of NF- $\kappa \mathrm{B}$ 

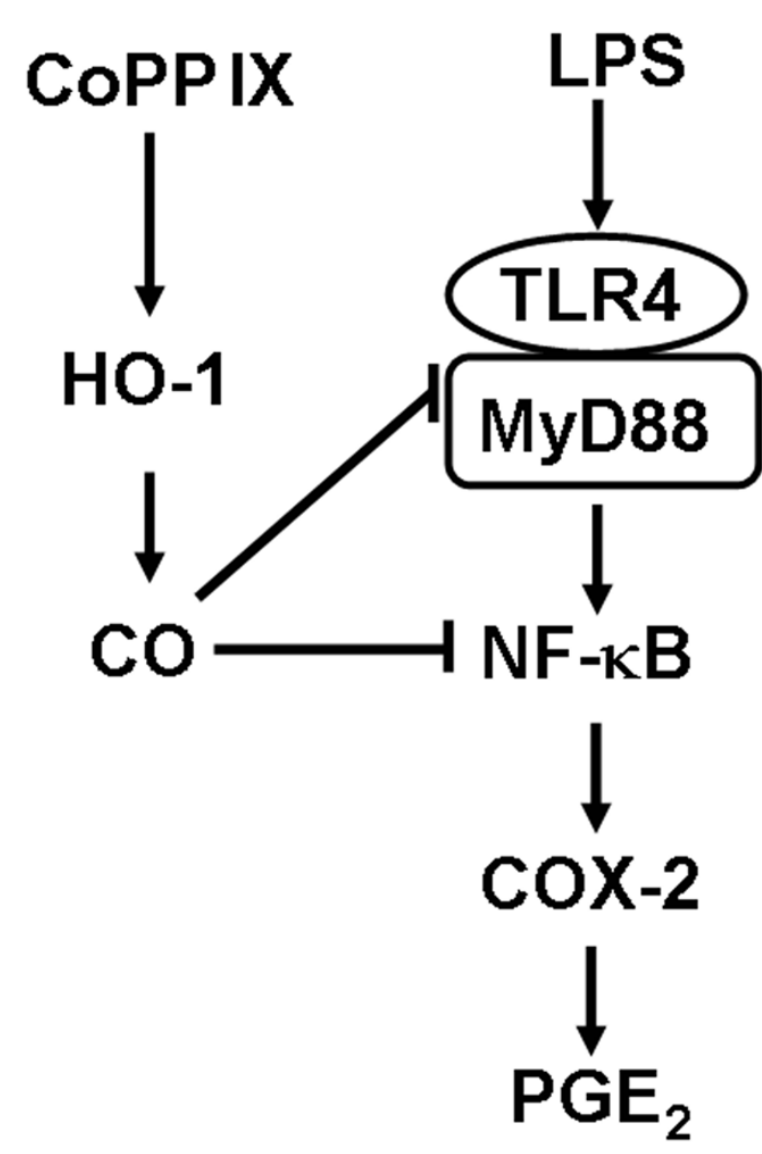

Figure 6 Down-regulation of LPS-induced COX-2 expression and $\mathrm{PGE}_{2}$ production by $\mathrm{HO}-1 / \mathrm{CO}$ in bEnd. 3 cells. LPS-induced COX-2 expression and $\mathrm{PGE}_{2}$ production were mediated by a TLR4/ MyD88/NF- $\kappa$ B pathway. Induction of $\mathrm{HO}-1$ by pretreatment with CoPP or infection with Adv-HO-1 attenuated LPS-induced COX-2 expression and $\mathrm{PGE}_{2}$ production in bEnd.3 cells. A HO-1 by-product, $\mathrm{CO}$, at least in part, attenuated LPS-induced COX-2 expression through interruption of TLR4/MyD88/NF- $\kappa$ B pathway in bEnd.3 cells.

activation by CoPP displays anti-inflammatory effects of $\mathrm{HO}-1$ in various cell types [26]. Interestingly, $\mathrm{CO}$ has been reported to modulate several transcription factors, including NF- $\kappa \mathrm{B}[30,31]$. In the blood/vascular system, pretreatment of human umbilical vein endothelial cells (HUVEC) with CO-RM2 attenuates the LPS-induced activation of NF- $\kappa \mathrm{B}$ [32]. Recently, $\mathrm{CO}$ has also been shown to block LPS-induced initial inflammatory response through inhibition of NF- $\kappa \mathrm{B}$ in human monocytes [35]. In the present study, we found that LPSinduced COX-2 expression and p65 activation was inhibited by pretreatment with CoPP and CO-RM2, suggesting that induction of $\mathrm{HO}-1 / \mathrm{CO}$ inhibits LPSinduced COX-2 by inhibition of NF- $\kappa \mathrm{B}$ in murine celebral endothelium.

In addition to NF- $\kappa \mathrm{B}$ inhibition by $\mathrm{HO}-1 / \mathrm{CO}$, other transcription factors, such as CCAAT/enhancer-binding protein (C/EBP) expression are decreased by $\mathrm{HO}-1 / \mathrm{CO}$ in LPS-treated RAW 264.7 cells [36] and activating protein (AP)-1 is also suppressed by hemin, an HO-1 inducer, in soleus muscles of Sprague-Dawley rats [39]. It is interesting that early growth response-1 (Egr-1) protein, which is a key transcription factor in regulating the inducible expression of microsomal PGE synthase 1 (mPGES-1) and therefore promotes $\mathrm{PGE}_{2}$ release [40], is also significantly reduced by an $\mathrm{HO}-1$ inducer, CoPP, in IL-1 $\beta$-treated chondrocytes [41]. All of NF- $\kappa \mathrm{B}, \mathrm{C} / \mathrm{EBP}$, $\mathrm{AP}-1$, and Egr-1 transcription factors are involved in $\mathrm{PGE}_{2}$ synthesis catalyzed by induction of either COX-2 or mPGES-1. The activation of these transcription factors is suppressed by induction of $\mathrm{HO}-1$ which exerts anti-oxidative and anti-inflammatory effects in several cell types [42], including endothelial cells [43]. We therefore hypothesized that there is a common mechanism in attenuation of these inflammation-related transcription factors by induction of $\mathrm{HO}-1 / \mathrm{CO}$ in these cells.

TLRs function as primary sensors of pathogens, which activate signaling pathways leading to the expression of cytokines [44]. It has been demonstrated that the signaling pathways are initiated by LPS binding to the TLR4 in endothelial cells [23]. Inflammatory signaling initiates when LPS binds to LPS-binding protein, which presents LPS to CD14. Binding of LPS to CD14 activates TLR4. Activation of TLR4 triggers the recruitment of myeloid differentiation factor (MyD88) and initiates NF- $\kappa$ B signaling pathway, leading to expression of inflammatory target proteins. In the present study, pretreatment with CO-RM2 attenuated the association between TLR4 and MyD88 (Figure 5D). CO-RM2 inhibited LPS-induced activation of NF- $\kappa$ B, which may be due to attenuation of TLR4/MyD88 signaling, consistent with results indicating that $\mathrm{CO}$ suppresses TLR4/MyD88 signaling in murine macrophages [45].

COX-2 has been suggested to contribute to LPS-induced cellular damage [3]. It has been reported that pretreatment with a selective COX-2 inhibitor protects neuronal cultures from LPS-induced cytotoxicity through attenuation of COX-2 expression and PGs synthesis [46]. Interestingly, COX-2-selective inhibitors have been reported to induce $\mathrm{HO}-1$ expression in various cell types $[47,48]$. These reports suggest that the protective effects of COX-2 inhibitors may be due to HO-1 induction [49]. Furthermore, it has been also reported that the COX-2 metabolite, $\mathrm{PGE}_{2}$, induces HO-1 through PKA and PI3K signaling pathways via EP2 receptors in C6 cells [50]. Induction of HO-1 may be a defensive response initiated by $\mathrm{PGE}_{2}$ and serve a critical role for a cytoprotective mechanism during oxidative stress. There seems to be an interesting interactive relationship between COX-2 and HO-1, that is, overexpression of COX-2 associated with $\mathrm{PGE}_{2}$ release induces $\mathrm{HO}-1$ expression which in turn inhibits COX-2 expression 
and therefore diminishes $\mathrm{PGE}_{2}$ production. The relationship between HO-1 and COX-2 is an interesting issue and needs detailed investigation.

As depicted in Figure 6, this study demonstrated that up-regulation of HO-1 inhibits LPS-mediated COX-2 expression and $\mathrm{PGE}_{2}$ synthesis in murine brain endothelial cells (bEnd.3). Treatment of bEnd.3 cells with LPS induces COX-2 protein and PGE2 via Toll-like receptor 4-mediated activation of NF- $\kappa$ B. However, pharmacologic induction or gene transfer of HO-1 blocks LPSmediated COX-2 expression and activity. This inhibitory effect of HO-1 on COX-2 expression was mediated through retardation of NF- $\kappa \mathrm{B}$ and could be reversed by an $\mathrm{HO}$ inhibitor, $\mathrm{ZnPP}$, or a $\mathrm{CO}$-scavenger, hemoglobin. Moreover, the exogenous administration of the $\mathrm{CO}$ releasing molecule, CO-RM2, mimics the effect of HO-1.

\section{Conclusions}

Our results show strong evidence that overexpression of HO-1/CO exerts an inhibitory effect on LPS-induced $\mathrm{COX}-2 / \mathrm{PGE}_{2}$ synthesis in cerebrovascular endothelial cells. Our results reinforce the emerging role of cerebrovascular endothelium-derived $\mathrm{HO}-1$ as a protector for preventing cerebral vascular inflammation triggered by bacterial infection.

\section{Author Details}

Department of Physiology and Pharmacology, Chang Gung University, Tao-Yuan, Taiwan

\author{
Acknowledgements \\ This work was supported by National Science Council, Taiwan and Chang \\ Gung Medical Research Foundation, Taiwan. Contract grant number: NSC97- \\ 2321-B-182-007, NSC98-2321-B-182-004, NSC96-2320-B-182-009, \\ CMRPD150253, CMRPD150313, CMRPD170492 and CMRPD180372. We thank \\ Mr. Li-Der Hsiao for his technical assistance during preparation of this \\ manuscript.
}

\section{Authors' contributions \\ RHS designed and performed experiments, acquisition and analysis of data, and drafted the manuscript. CMY has conceived of the study, participated in its design and coordination, has been involved in drafting the manuscript and revising it critically for important intellectual content and have given final approval of the version to be published. The authors have read and approved the final version of this manuscript.}

\section{Competing interests}

The authors declare that they have no competing interests.

Received: 16 August 2010 Accepted: 30 November 2010 Published: 30 November 2010

\section{References}

1. Cohen J: The immunopathogenesis of sepsis. Nature 2002, 420:885-891.

2. Su GL, Klein RD, Aminlari A, Zhang HY, Steinstraesser L, Alarcon WH, Remick DG, Wang SC: Kupffer cell activation by lipopolysaccharide in rats: role for lipopolysaccharide binding protein and toll-like receptor 4 . Hepatology 2000, 31:932-936.

3. Ejima K, Layne MD, Carvajal IM, Kritek PA, Baron RM, Chen YH, Vom Saal J, Levy BD, Yet SF, Perrella MA: Cyclooxygenase-2-deficient mice are resistant to endotoxin-induced inflammation and death. FASEB J 2003 17:1325-1327.

4. Fletcher JR: Eicosanoids: critical agents in the physiological process and cellular injury. Arch Surg 1993, 128:1192-1196.

5. Williams JA, Shacter E: Regulation of macrophage cytokine production by prostaglandin $E_{2}$ : distinct roles of cyclooxygenase-1 and -2 . J Biol Chem 1997, 272:25693-25699.

6. Eklind S, Mallard C, Leverin AL, Gilland E, Blomgren K, Mattsby-Baltzer I, Hagberg $\mathrm{H}$ : Bacterial endotoxin sensitizes the immature brain to hypoxic-ischemic injury. Eur J Neurosci 2001, 13:1101-1106.

7. Fan LW, Pang Y, Lin S, Rhodes PG, Cai Z: Minocycline attenuates lipopolysaccharide-induced white matter injury in the neonatal rat brain. Neuroscience 2005, 133:1359-1368.

8. Fan LW, Mirchell HJ, Tien LT, Zheng B, Pang Y, Rhodes PG, Cai Z: Alphaphenyl-n-tert-butyl-nitrone reduces lipopolysaccharide-induced white matter injury in the neonatal rat brain. Dev Neurobiol 2008, 68:365-378.

9. Wang X, Rousset Cl, Hagberg H, Mallard C: Lipopolysaccharide-induced inflammation and perinatal brain injury. Semin Fetal Neonatal Med 2006, 11:343-353.

10. Brouard S, Otterbein LE, Anrather J, Tobiasch E, Bach FH, Choi AM: Carbon monoxide generated by heme oxygenase- 1 suppresses endothelial cell apoptosis. J Exp Med 2000, 192:1015-1026.

11. Nakao A, Kaczorowski DJ, Zuckerbraun BS, Lei J, Faleo G, Deguchi K, McCurry KR, Billiar TR, Kanno S: Galantamine and carbon monoxide protect brain microvascular endothelial cells by heme oxygenase-1 induction. Biochem Biophys Res Commun 2008, 367:674-679.

12. Yachie A, Niida $Y$, Wada T, Igarashi N, Kaneda H, Toma T, Ohta K, Kasahara Y, Koizumi S: Oxidative stress causes enhanced endothelial cell injury in human heme oxygenase-1 deficiency. J Clin Invest 1999, 103:129-135.

13. Alcaraz MJ, Fernandez P, Guillen MI: Anti-inflammatory actions of the heme oxygenase-1 pathway. Curr Pharm Des 2003, 9:2541-2551.

14. Bauer I, Wanner GA, Rensing H, Alte C, Miescher EA, Wolf B, Pannen BH, Clemens MG, Bauer M: Expression pattern of heme oxygenase isoenzymes 1 and 2 in normal and stress-exposed rat liver. Hepatology 1998, 27:829-838.

15. Ryter SW, Alam J, Choi AM: Heme oxygenase/carbon monoxide: from basic science to therapeutic application. Physiol Rev 2006, 86:583-650.

16. Bernardini C, Zannoni A, Bacci ML, Forni M: Protective effect of carbon monoxide pre-conditioning on LPS-induced endothelial cell stress. Cell Stress Chaperones 2010, 15:219-24.

17. Seed MP, Willoughby DA: COX-2, HO NO! Cyclooxygenase-2, heme oxygenase and nitric oxide synthase: their role and interactions in inflammation. Inflamm Res 1997, 46:279-281.

18. Wagener FA, Volk HD, Willis D, Abraham NG, Soares MP, Adema GJ, Figdor CG: Different faces of the heme-heme oxygenase system in inflammation. Pharmacol Rev 2003, 55:551-571.

19. Lee CW, Chien CS, Yang CM: Lipoteichoic acid-stimulated p42/p44 MAPK activation via Toll-like receptor 2 in tracheal smooth muscle cells. Am J Physiol Lung Cell Mol Physiol 2004, 286:L921-L930.

20. Hsieh HL, Wu CY, Hwang TL, Yen MH, Parker P, Yang CM: BK-induced cytosolic phospholipase $A_{2}$ expression via sequential PKC- $\delta, p 42 / p 44$ MAPK, and NF-KB activation in rat brain astrocytes. J Cell Physiol 2006 206:246-254.

21. Tenhunen R, Marver HS, Schmid R: The enzymatic catabolism of hemoglobin: stimulation of microsomal heme oxygenase by hemin. $J$ Lab Clin Med 1970, 75:410-421.

22. Nakao S, Ogata $Y$, Shimizu-Sasaki E, Yamazaki M, Furuyama S, Sugiya $H$ : Activation of NF-KB is necessary for IL-1 $\beta$-induced cyclooxygenase-2 (COX-2) expression in human gingival fibroblasts. Mol Cell Biochem 2000, 209:113-118.

23. Dauphinee SM, Karsan A: Lipopolysaccharide signaling in endothelial cells. Lab Invest 2006, 86:9-22.

24. Li Volti G, Seta F, Schwartzman ML, Nasjletti A, Abraham NG: Heme oxygenase attenuates angiotensin II-mediated increase in cyclooxygenase-2 activity in human femoral endothelial cells. Hypertension 2003, 41:715-719.

25. Megías J, Guillén MI, Clérigues V, Rojo Al, Cuadrado A, Castejón MA Gomar F, Alcaraz MJ: Heme oxygenase-1 induction modulates microsomal prostaglandin E synthase-1 expression and prostaglandin $E_{2}$ 
production in osteoarthritic chondrocytes. Biochem Pharmacol 2009, 77:1806-1813

26. Tsoyi K, Kim HJ, Shin JS, Kim DH, Cho HJ, Lee SS, Ahn SK, Yun-Choi HS, Lee JH, Seo HG, Chang KC: HO-1 and JAK-2/STAT-1 signals are involved in preferential inhibition of iNOS over COX-2 gene expression by newly synthesized tetrahydroisoquinoline alkaloid, CKD712, in cells activated with lipopolysacchride. Cell Signal 2008, 20:1839-1847.

27. Wen T, Wu ZM, Liu Y, Tan YF, Ren F, Wu H: Upregulation of heme oxygenase- 1 with hemin prevents D-galactosamine and lipopolysaccharide-induced acute hepatic injury in rats. Toxicology 2007, 237:184-193.

28. Alcaraz MJ, Guillen Ml, Ferrandiz ML, Megias J, Motterlini R: Carbon monoxide-releasing molecules: a pharmacological expedient to counteract inflammation. Curr Pharm Des 2008, 14:465-472.

29. Chung SW, Liu X, Macias AA, Baron RM, Perrella MA: Heme oxygenase-1derived carbon monoxide enhances the host defense response to microbial sepsis in mice. J Clin Invest 2008, 118:239-247.

30. Morse D, Pischke SE, Zhou Z, Davis RJ, Flavell RA, Loop T, Otterbein SL, Otterbein LE, Choi AM: Suppression of inflammatory cytokine production by carbon monoxide involves the JNK pathway and AP-1. J Biol Chem 2003, 278:36993-36998.

31. Sarady JK, Otterbein SL, Liu F, Otterbein LE, Choi AM: Carbon monoxide modulates endotoxin-induced production of granulocyte macrophage colony-stimulating factor in macrophages. Am J Respir Cell Mol Biol 2002 27:739-745.

32. Sun B, Zou X, Chen Y, Zhang P, Shi G: Preconditioning of Carbon Monoxide Releasing Molecule-derived CO Attenuates LPS-induced Activation of HUVEC. Int J Biol Sci 2008, 4:270-278.

33. Ryter SW, Otterbein LE, Morse D, Choi AM: Heme oxygenase/carbon monoxide signaling pathways: Regulation and functional significance. Mol Cell Biochem 2002, 234-235:249-263.

34. Wang XM, Kim HP, Nakahira K, Ryter SW, Choi AM: The heme oxygenase$1 /$ carbon monoxide pathway suppresses TLR4 signaling by regulating the interaction of TLR4 with caveolin-1. J Immunol 2009, 182:3809-3818.

35. Chhikara M, Wang S, Kern SJ, Ferreyra GA, Barb JJ, Munson PJ, Danner RL: Carbon monoxide blocks lipopolysaccharide-induced gene expression by interfering with proximal TLR4 to NF-KB signal transduction in human monocytes. PLoS ONE 2009, 4:e8139.

36. Suh GY, Jin Y, Yi AK, Wang XM, Choi AM: CCAAT/enhancer-binding protein mediates carbon monoxide-induced suppression of cyclooxygenase-2. Am J Respir Cell Mol Biol 2006, 35:220-226.

37. Kaizaki A, Tanaka S, Ishige K, Numazawa S, Yoshida T: The neuroprotective effect of heme oxygenase $(\mathrm{HO})$ on oxidative stress in HO-1 siRNAtransfected HT22 cells. Brain Res 2006, 1108:39-44.

38. Weihong Pan, Chuanhui Yu, Hung Hsuchou, Kastin JAbba: The role of cerebral vascular NF-KB in LPS-induced inflammation: Differential regulation of efflux transporter and transporting cytokine receptors. Cell Physiol Biochem 2010, 25:623-630.

39. Ndisang JF, Jadhav $A$ : Heme oxygenase system enhances insulin sensitivity and glucose metabolism in streptozotocin-induced diabetes. Am J Physiol Endocrinol Metab 2009, 296:E829-E841.

40. Cheng S, Afif H, Martel-Pelletier J, Pelletier JP, Li X, Farrajota K: Activation of peroxisome proliferator-activated receptor- $\gamma$ inhibits interleukin-1 $\beta$ induced membrane-associated prostaglandin $\mathrm{E}_{2}$ synthase- 1 expression in human synovial fibroblasts by interfering with Egr-1. J Biol Chem 2004, 279:22057-22065.

41. Megías J, Guillén Ml, Clérigues V, Rojo Al, Cuadrado A, Castejón MA, Gomar F, Alcaraz MJ: Heme oxygenase-1 induction modulates microsomal prostaglandin E synthase-1 expression and prostaglandin E2 production in osteoarthritic chondrocytes. Biochem Pharmacol 2009, 77:1806-1813.

42. Alcaraz MJ, Fernandez P, Guillen MI: Anti-inflammatory actions of the heme oxygenase-1 pathway. Curr Pharm Des 2003, 9:2541-2551.

43. Brouard S, Otterbein LE, Anrather J, Tobiasch E, Bach FH, Choi AM: Carbon monoxide generated by heme oxygenase 1 suppresses endothelial cell apoptosis. J Exp Med 2000, 192:1015-1026.

44. Akira S, Takeda K: Toll-like receptor signalling. Nat Rev Immunol 2004, 4:499-511.

45. Wang XM, Kim HP, Nakahira K, Ryter SW, Choi AMK: The heme oxygenase$1 /$ carbon monoxide pathway suppresses TLR4 signaling by regulating the interaction of TLR4 with caveolin-1. J Immunol 2009, 182:3809-3818.
46. Araki E, Forster C, Dubinsky JM, Ross ME, ladecola C: Cyclooxygenase-2 inhibitor NS-398 protects neuronal cultures from lipopolysaccharideinduced neurotoxicity. Stroke 2001, 32:2370-2375.

47. Alcaraz MJ, Habib A, Cre'minon C, Vicente AM, Lebret M, Le'vy-Toledano S, Maclouf J: Heme oxygenase-1 induction by nitric oxide in RAW 264.7 macrophages is upregulated by a cyclo-oxygenase- 2 inhibitor. Biochim Biophys Acta 2001, 1526:13-16.

48. Fernández P, Guillén Ml, Gomar F, Aller E, Molina P, Alcaraz MJ: A novel cyclo-oxygenase-2 inhibitor modulates catabolic and anti-inflammatory mediators in osteoarthritis. Biochem Pharmacol 2004, 68:417-421.

49. Han S, Roman J: COX-2 inhibitors suppress lung cancer cell growth by inducing p21 via COX-2 independent signals. Lung Cancer 2006, 51:283-296.

50. Park MK, Kang YJ, Ha YM, Jeong JJ, Kim HJ, Seo HG, Lee JH, Chang KC: EP2 receptor activation by prostaglandin $E_{2}$ leads to induction of HO-1 via PKA and PI3K pathways in C6 cells. Biochem Biophys Res Commun 2009, 379:1043-1047.

doi:10.1186/1742-2094-7-86

Cite this article as: Shih and Yang: Induction of heme oxygenase-1 attenuates lipopolysaccharide-induced cyclooxygenase-2 expression in mouse brain endothelial cells. Journal of Neuroinflammation 2010 7:86.

\section{Submit your next manuscript to BioMed Central and take full advantage of:}

- Convenient online submission

- Thorough peer review

- No space constraints or color figure charges

- Immediate publication on acceptance

- Inclusion in PubMed, CAS, Scopus and Google Scholar

- Research which is freely available for redistribution
C Biomed Central 